The systematic part of the work contains a most useful revision of the known species of Chætognatha with a detailed key giving brief diagnoses of the genera and species, as well as a fuller statement of characters, with measurements of many specimens in the case of most species.

In the very full discussion of the problems of distribution, illustrated by many tables, we find that our author considers that his data contain numerous examples illustrating lack of uniformity in distribution. Some of these examples are as follows: In two hauls of the same net in the same region on the same day the number of Sagitta bipunctata varied from fifteen at $6.20 \mathrm{a} . \mathrm{m}$. to one at 7.20 a.m. per unit volume of water. On another day, under similar conditions, the number varied from twenty-five to one, and on another day similarly from one to fifty-six, and on still another occasion from I 35 to one. "Other instances might be cited, but enough have been given to show that the surface-distribution of $S$. bipunctata is not constant for any length of time, even in very small areas. The objection will be made that hydrographic and meteorological conditions change rapidly near the coast, but remain constant on the high seas. I doubt the validity of such an objection. In the first place, owing to variations in wind, rain, light, barometric pressure, heat, \&c., it is very improbable that hydrographic and meteorological conditions even approach constancy on the high seas. In the second place, some of the above examples show that $S$. bipunctata varied in abundance even when these conditions. so far as known, remained constant during the period within which the contrasted hauls were made."

The author finds himself in agreement with similar observations that have been taken in recent years in the Irish Sea, and comes to the conclusion that "we are therefore compelled to acknowlege a very definite causal relation between rate of reproduction and variations in the quantity of plankton." He discusses the influence of other organisms on the abundance of plankton, and illustrates it by the effect of "red-water," due to the presence of enormous numbers of the dinoflagellate Gonyaulax, and recognises, consequently, that to estimate adequately the quantity of plankton in a given area of the sea we must consider far more than the physical and chemical conditions, and must not omit the biological influences involving the effects of growth, reproduction, food-relations, and other activities of the organisms concerned. As Kofoid (1903) has demonstrated, there are variations in the quantity of plankton which are nearly, if not entirely, independent of hydrographic and meteorological conditions.

Mr. Michael shows that Sagitta bipunctata, the commonest species that he deals with, is "epiplanktonic," and, moreover, migrates towards the surface at night and into deeper zones in the day. In the surface-nets this species attains its morning maximum within an hour after sunrise, and its evening maximum within an hour after sunset. He considers that it is probable that the species in its diurnal migrations is constantly movirg towards that zone of water in which "twilight conditions" are to be found. The effects of salinity and temperature are also investigated in detail, and the conclusion that our author arrives at is that "probably light has more pronounced effect on vertical distribution than temperature or salinity, because its variations are more regular and periodic."

It is interesting to find that in a later paper in the same series from the University of California, viz., C. O. Esterly on the distribution of the Copepoda of the San Diego region, precisely the same general conclusions as to irregularity of distribution of the plankton are arrived at. In speaking of the absence of any uniformity, the author of this later paper says: "Instances of this could be given almost without number in regard to the distribution of the Copepoda of this region." The marine biologists of the Californian coast are clearly to be congratulated on the thoroughness with which their investigations are being carried out, and on the sound conclusions at which they are arriving. W. A. H.

\section{PROF. FRANCIS GOTCH, F.R.S.}

THE phenomena of life and their cessation at death present varied interests attracting to their investigation minds of very diverse type. Thus when the foremost ranks of physiology show a new-made gap, and a distinguished service of some one particular kind is at an end for ever, the loss to the science is not readily repaired. It is then too clear that the gifts which have vanished have differed from those that are left more than in degrees of excellence. Thus deeply at the present time physiology suffers by the death of the late Prof. Francis Gotch. His name is significant of a world-wide reputation. His personality was obviously individual, and in its peculiarities excellent.

Nothing that can be said in the near future can add to or detract from his established reputation. A master of the technique in one particular line, his measurements stand until that technique undergoes unforeseen developments and improvements. In that branch of the subject which he had made his own he had contributed to knowledge a long series of very precise data, placed with great skill at points of salient interest. Feeling no need for the incentives provided by explanatory hypotheses, testing no particular form of speculation, he has patiently and with great ingenuity assisted in a fundamentally essential survey of the physical evidences of life as studied in nerve, muscle, the retina, the special organs of electrical fishes, and in the central nervous system. Further than this, he was a distinguished authority upon the literature of this subject, and a writer of valued summaries and lucid historical articles.

Judged from his writings, he was what I have thus too briefly stated, namely, a dispassionate contributor, and a cold analyst, of evidence. Strange as may seem the contrast, to his students he was a magician, a marvellous weaver of deft NO. 2282 , VOL. 917 
words, a master of dramatic effects, who, with a sure hand, shaped before their eyes a brilliant texture of knowledge, ending always by laying down a finished carpet on which they might walk with reposeful security towards their own looms. His excellence in teaching the general groundwork of the subject was unique. Backed, as it was, by admirable practical classes, in which the niceties of technical skill required for the collection of evidence were instilled, and a whole field of evidence of a particular type displayed, it provided an educational basis of unsurpassable value. No one acquainted with his work will scent exaggeration in the statement that in this matter he was superb.

Outcome as this excellence was, in part, of unstinted effort and elaborate pains, and of a fully-developed desire to satisfy a genuine ambition for success in such teaching, it was also largely the result of native temperament and talent. A cheerful and courteous man, kindly to the core, generous to a fault. Humble with a knowledge of his own limitations, reverently serving undiscussed ideals, alight with enthusiasm. Of wide sympathy, singularly well-informed, of great culture, and most refined taste. Qualities such as these, and an evident sincerity in his devotion to his subject, necessarily won home to receptive and humane minds.

If at any time his manner caused irritation, then I take it this may be attributed to an excellent and uncommon quality, which was at times of great public service. He was essentially æsthetic, exquisitely sensitive to every light and shade in the inanimate, and in the animate character of his surroundings necessarily seeking harmonies, and as necessarily, therefore, arranging them. Neither inviting admiration nor in any way impelled towards dominance, nevertheless he was alway: quietly to the front to make certain that the scene was set, the players grouped, and a satisfying ensemble produced. Wherever such initiative was welcomed, as often in social matters where it is most rare, he was admirably successful. Arriving in Liverpool in 1891 as the first occupant of the newly endowed Holt Chair of Physiology, the complete sincerity of these qualities enabled him to give invaluable support to those able men who were then watchfully tending the growth of the university spirit within its boundaries. There, with his wife, he gained a great social success without underlying thought other than to give his best, and to obtain the best from others. His accomplished predecessor, citizens of great importance and benevolence, colleagues and students, he turned into grateful friends not of himself alone, but into mutual friends. That he was so signally capable of assisting in an obviously large and progressive movement, the development of university ideals of freedom in thought, in work, and in teaching, within a great and typical centre of commercial industry, must have had a reflected influence on his own character, and given him an added courage and skill in dealing with public affairs.

$$
\text { NO. } 2282 \text {, VOL. } 9 \mathrm{I}]
$$

Leaving Liverpool in I895 to occupy the Waynflete Chair of Physiology in Oxford, he returned to scenes already familiar. He was frankly pleased with this great and different opportunity; thinking it no small thing that he was entrusted with the banner carried so loftily by his distinguished master, whose influence had been largely responsible for the shaping of his career. If it is right to regard as ambition the desire to win complete recognition in a life-work not chosen from motives of dominance or gain, then it was his ambition which was now completely satisfied. In return for this satisfaction he endeavoured to perform the duties of this post of honour with anxious care and unflagging industry, shirking no responsibility. That he has proved equal to the task is evident from the continued success of the Oxford school of physiology, and from the value and numbers of its alumni who have passed out into, and maintain with credit, positions of great importance.

To his personal friends who have tramped through the mists of Cumberland fells, or wandered through the picture galleries and churches of foreign towns, with a companion so brimful of cheer and interest, or who have heard him tell the tale of his one participation in a cavalry charge in Zululand, or have listened to his renderings of Devonshire songs, his death has brought an intimate sense of loss.

To his wife and family, the centre of so much mutual love and understanding, we can do no more than offer sincere sympathy.

\section{J. S. Macdonald.}

\section{NOTES.}

DR. R. VON LENDENFELD, professor of zoology and rector of the German University of Prague, who died on July 3, aged fifty-six, had many friends and acquaintances in this country, where he resided for a time. He began his scientific career by travelling in Australia, where he studied chiefly marine sponges and cœlenterates. The results of his investigations were published, partly in English, as "A Monograph of the Australian Sponges," and other papers in the Proceedings of the Linnean Society of New South Wales, and partly in German, as a series of memoirs, entitled "Ueber Cölenteraten der Südsee." After his Australian trip he was for a time assistant in the zoological department at University College, London, and while in England produced, besides other works, his "Monograph of the Horny Sponges," published by the Royal Society, based chiefly upon material collected in Australia. Much of his earlier work was somewhat Haeckelian in the method of treatment, and later investigation has failed to confirm the accuracy of many of his statements, notably the existence of a nervous system in sponges alleged by him. Subsequently he published some works on sponges jointly with Prof. F. E. Schulze, of Berlin, and later, after he obtained the chair of zoology at Czernowitz, he published a monograph of the sponges of the Adriatic in a series of memoirs. When called to Prague he continued to publish, from time to time, systematic 